\title{
Valorization of Wild Apple (Malus spp.) By-Products as a Source of Essential Fatty Acids, Tocopherols and Phytosterols with Antimicrobial Activity
}

\author{
Vitalijs Radenkovs ${ }^{1, * \mathbb{C}}$, Jorens Kviesis ${ }^{2}$, Karina Juhnevica-Radenkova ${ }^{1}$, Anda Valdovska ${ }^{3,4}$, \\ Tõnu Püssa ${ }^{5}$, Maris Klavins ${ }^{2}$ and Inese Drudze ${ }^{1}$ \\ 1 Processing and Biochemistry Department, Institute of Horticulture, Latvia University of Life Sciences and \\ Technologies, Graudu Str. 1, LV-3701 Dobele, Latvia; karina.juhnevica-radenkova@llu.lv (K.J.-R.); \\ inese.drudze@puresdis.lv (I.D.) \\ 2 Department of Environmental Science, University of Latvia, Jelgavas Str. 1, LV-1004 Riga, Latvia; \\ jorens.kviesis@inbox.lv (J.K.); maris.klavins@lu.lv (M.K.) \\ 3 Faculty of Veterinary Medicine, Latvia University of Life Sciences and Technologies, 8 K. Helmana Str., \\ LV-3004 Jelgava, Latvia; Anda.Valdovska@llu.lv \\ 4 Research Laboratory of Biotechnology, Latvia University of Life Sciences and Technologies, Strazdu Str. 1, \\ LV-3004 Jelgava, Latvia \\ 5 Chair of Food Hygiene and Veterinary Public Health, Estonian University of Life Sciences, Kreutzwaldi \\ 56/3, 51014 Tartu, Estonia; tonu.pyssa@emu.ee \\ * Correspondence: vitalijs.radenkovs@llu.lv; Tel.: + 371-2881-1231; Fax: +371-6378-1718
}

Received: 8 October 2018; Accepted: 22 October 2018; Published: 24 October 2018

\begin{abstract}
The amplified production of fruit as well as burgeoning demand for plant-made food products have resulted in a sharp increase of waste. Currently, millions of tons of by-products are either being discarded or utilized rather ineffectively. However, these by-products may be processed and further incorporated as functional ingredients in making high-value food products with many physiological and biochemical effects. The chemical analysis of pomace oils using gas chromatography-mass spectrometry (GC/MS) and reversed-phase-liquid chromatography coupled with fluorescence detector (RP-HPLC/FLD) systems led to the identification and quantification of 56 individual lipophilic compounds including unsaturated, polyunsaturated and saturated fatty acids, as well as phytosterols and four homologs of tocopherol. The oils recovered from by-products of Malus spp. (particularly cv. "Ola") are rich in fatty acids such as linolenic (57.8\%), $\alpha$-linolenic $(54.3 \%)$, and oleic $(25.5 \%)$. The concentration of total tocopherols varied among the Malus species and dessert apples investigated, representing the range of $16.8-30.9 \mathrm{mg} \mathrm{mL}^{-1}$. The highest content of total tocopherols was found in M. Bernu prieks, followed by M. cv. "Ola", and M. $\times$ Soulardii pomace oils. A significantly higher amount of $\delta$-tocopherol was established in the oil of $M$. Bernu prieks, indicating that this species could be utilized as a natural and cheap source of bioactive molecules. $\beta$-Sitosterol was the prevalent compound determined in all tested pomace oils with a percentage distribution of 10.3-94.5\%. The main triterpene identified in the oils was lupeol, which varied in the range of $0.1-66.3 \%$. A targeted utilization of apple pomace would facilitate management of tons of by-products and benefit the environment and industry.
\end{abstract}

Keywords: Malus spp.; oil; FAMEs; tocopherols; carotenoids; MIC

\section{Introduction}

Domesticated apple (Malus $\times$ domestica Borkh.) is one of the most important fruit crops worldwide. According to FAOSTAT (2018) [1], the world production of apple in the last five decades has increased 
by $424 \%$ from 17.0 million tons in 1961 to 89.3 million tons in 2016 . Leading production nations include (in descending order) China, USA, Poland, Turkey, Iran, Italy, Russia, Uzbekistan, and Ukraine. There are hundreds of apple cultivars, but only five currently dominate world production: Fuji, Golden Delicious, Delicious, Granny Smith, and Gala. Currently, dessert apples are processed into many food products including juice (2.1 million liters among the 28 European Union member states (EU-28)) [2], apple sauce, slices (dried, frozen and canned) and cider (sweet and hard) (1.4 million liters in the EU-28) [3]. The increased production of apples as well as burgeoning demand for plant-derived food products have resulted in dramatic increase of waste. The food processing sector contributes the most to food waste-in 2012, this was estimated to be 17 million tons or $19 \%$ of a total amount of 87.6 million tons of food waste generated in the EU-28, based on data provided by Fusions EU Project [4]. In large-scale apple juice production, $75 \%$ of the apple are utilized for juice, while the remaining $25 \%$ are discarded as waste or utilized rather inefficiently [5]. These by-products may be processed and further incorporated as ingredients in making high-value functional food products (cereal bars, cookies, muffins, bread and fermented milk products) with many physiological and biochemical effects [6].

Dessert apple fruits as well as their by-products have been studied in terms of their chemical composition [7,8], along with their positive health effects [8]. However, rather little is known concerning the lipophilic composition of crab apples. Crab apples, also known as wild apples, belong to the genus Malus (Rosaceae family) and are currently used not only for ornamental purposes, but also are one of the most important source of seeds with an increased concentration of all four homologs of tocopherol $(\alpha, \beta, \gamma$ and $\delta)$ [9], and hydrophilic antioxidant substances for the food and cosmetic industries [10]. Food industries have been increasingly focused on developing high-quality food products with increased functionality, therefore crab apples have gained an increasing interest in the last decades [8,11]. Crab apples are used in the preparation of jellies, jams, beverages, and wines [12]. Dadwal et al. [12] found that extracts obtained from either pulp or seeds of Himalayan crab apple fruits (M. baccata) not only contained moderate concentrations of polyphenols (phloretin and phloridzin), but also fatty acid molecules such as palmitic acid, ethyl palmitate, methyl petroselinate and linolein, which are well recognized for medicinal uses [13]. Moreover, Górnaś et al. [14] reported that the apple seeds recovered from dessert and crab apple are a promising source of oils, which also contain phytosterols, mainly $\beta$-sitosterol.

The most common phytosterols in the human diet are $\beta$-sitosterol, campesterol, and stigmasterol [15]. In vitro studies suggest that the consumption of foods or supplements enriched with phytosterols may be a partial way to reduce serum low-density lipoprotein (LDL) cholesterol levels by reducing intestinal cholesterol absorption [16]. Phytosterols have also been found to be effective in preventing lipoprotein oxidation in mice fed with high-fat diets, thus showing anticancer effects [17]. Recent studies have reported that the by-products of Malus genus have potential to be used in the production of therapeutic substances with a wide application in pharmaceutical and natural cosmetic industries, thus contributing to the reduction of waste generated during apple processing $[9,14,18]$. The main objective of this study, analysis of the lipophilic constituents from the pomace of Malus crab apple, reflects the growing interest in finding new approaches for the recovery of by-products generated during fruit processing.

\section{Results and Discussion}

\subsection{FAMEs of Crab Apple Pomace Oil}

The composition of FA in oils recovered from the pomace of four crab and one dessert apples analyzed using GC-MS are shown in Table 1. 
Table 1. Content of fatty acids (FAME derivatives) and tocopherols (Ts) in pomace oils recovered from Malus spp. crab apples, $\mathrm{mg} \mathrm{mL}^{-1}$.

\begin{tabular}{|c|c|c|c|c|c|c|}
\hline Compound & Retention Index & "Gita" & Malus soulardii & Bernu Prieks & "Ola" & Berzukroga Dzeltenais \\
\hline \multicolumn{7}{|l|}{ FAs } \\
\hline Dodecanoic acid & 1758 & n.d. & $7.2 \pm 0.0^{\mathrm{a}}$ & $7.5 \pm 0.0^{\mathrm{a}}$ & $3.6 \pm 0.0^{c}$ & $5.3 \pm 0.1^{b}$ \\
\hline Tetradecanoic acid & 1965 & $9.2 \pm 0.0^{\mathrm{a}}$ & $8.2 \pm 0.1^{b}$ & $8.1 \pm 0.1^{b}$ & $3.9 \pm 0.0^{\mathrm{d}}$ & $6.0 \pm 0.0^{c}$ \\
\hline 9-Oxononanoic acid & 2016 & n.d. & n.d. & n.d. & $4.9 \pm 0.0^{\mathrm{a}}$ & $5.6 \pm 0.0^{\mathrm{a}}$ \\
\hline 9,9-Dimethoxynonanoic acid & 2050 & n.d. & $7.3 \pm 0.1^{b}$ & $8.9 \pm 0.0^{\mathrm{a}}$ & $5.1 \pm 0.0^{c}$ & $4.6 \pm 0.0^{c}$ \\
\hline Nonanedioic acid & 2092 & $9.6 \pm 0.0^{\mathrm{a}}$ & $8.3 \pm 0.1^{b}$ & $9.1 \pm 0.0^{\mathrm{ab}}$ & n.d. & n.d. \\
\hline Hexadecanoic acid & 2165 & $44.8 \pm 0.2^{d}$ & $56.8 \pm 1.6^{c}$ & $71.3 \pm 1.3^{b}$ & $70.9 \pm 1.7^{\mathrm{b}}$ & $81.5 \pm 2.7^{\mathrm{a}}$ \\
\hline (Z)-7-Hexadecenoic acid & 2186 & n.d. & $7.1 \pm 0.2$ & n.d. & n.d. & n.d. \\
\hline (Z)-9-Hexadecenoic acid & 2192 & $9.5 \pm 0.1^{\mathrm{a}}$ & $7.2 \pm 0.2^{b}$ & $7.9 \pm 0.4^{b}$ & n.d. & n.d. \\
\hline Heptadecanoic acid & 2261 & n.d. & n.d. & n.d. & $3.6 \pm 0.0^{b}$ & $4.7 \pm 0.1^{\mathrm{a}}$ \\
\hline Octadecanoic acid & 2367 & $18.6 \pm 0.1^{b}$ & $16.3 \pm 0.1^{\mathrm{c}}$ & $22.2 \pm 0.3^{\mathrm{a}}$ & $14.4 \pm 0.2^{\mathrm{d}}$ & $9.2 \pm 0.1 \mathrm{e}$ \\
\hline (Z)-9-Octadecenoic acid & 2385 & $67.1 \pm 0.3^{\mathrm{e}}$ & $95.8 \pm 0.4^{\mathrm{d}}$ & $136.0 \pm 2.1^{\mathrm{c}}$ & $206.9 \pm 1.8^{a}$ & $164.1 \pm 2.1^{b}$ \\
\hline 9,10-Dihydroxystearate & 2395 & $1.5 \pm 0.0^{\mathrm{ac}}$ & $1.6 \pm 0.1^{\mathrm{ac}}$ & $1.1 \pm 0.0 \mathrm{ab}$ & $0.8 \pm 0.0^{\mathrm{b}}$ & $1.0 \pm 0.0 \mathrm{bc}$ \\
\hline (Z,Z)- 9,12-Octadecadienoic acid & 2433 & $149.0 \pm 0.2 \mathrm{e}$ & $193.5 \pm 4.0^{\mathrm{d}}$ & $307.8 \pm 4.6^{c}$ & $468.8 \pm 3.1^{\mathrm{a}}$ & $377.9 \pm 2.2^{b}$ \\
\hline$(\mathrm{Z}, \mathrm{Z}, \mathrm{Z})-9,12,15$-Octadecatrienoic acid & 2496 & $14.6 \pm 0.1^{\mathrm{c}}$ & $19.4 \pm 0.4^{\mathrm{b}}$ & $29.5 \pm 0.6^{\mathrm{a}}$ & $14.6 \pm 0.3^{c}$ & $9.9 \pm 0.0^{\mathrm{d}}$ \\
\hline Eicosanoic acid & 2571 & $13.7 \pm 0.1^{\mathrm{a}}$ & $9.6 \pm 0.0^{b}$ & $14.4 \pm 0.2^{\mathrm{a}}$ & $7.9 \pm 0.1^{c}$ & $5.8 \pm 0.0^{\mathrm{d}}$ \\
\hline (Z)-11-Eicosenoic acid & 2588 & $10.2 \pm 0.1$ & n.d. & n.d. & n.d. & n.d. \\
\hline Docosanoic acid & 2781 & n.d. & $9.7 \pm 0.0^{\mathrm{a}}$ & $9.6 \pm 0.0^{\mathrm{a}}$ & $5.8 \pm 0.0^{b}$ & $5.0 \pm 0.0^{\mathrm{b}}$ \\
\hline $\begin{array}{c}\text { Nonacosan-10-ol } \\
\text { Ts }\end{array}$ & 3046 & $6.6 \pm 0.1^{b}$ & $16.7 \pm 0.2^{\mathrm{a}}$ & $4.9 \pm 0.0^{c}$ & $3.9 \pm 0.1^{\mathrm{d}}$ & $3.2 \pm 0.0^{\mathrm{d}}$ \\
\hline$\delta$-Tocopherol & 8.1 & $3.6 \pm 0.1^{\mathrm{c}}$ & $3.1 \pm 0.1^{c}$ & $21.5 \pm 0.3^{\mathrm{a}}$ & $4.8 \pm 0.1^{b}$ & $3.6 \pm 0.1^{c}$ \\
\hline$\beta$-Tocopherol & 9.8 & $2.7 \pm 0.1^{b}$ & $3.9 \pm 0.1^{\mathrm{a}}$ & $2.9 \pm 0.1^{b}$ & $2.6 \pm 0.1^{b}$ & $3.0 \pm 0.1^{b}$ \\
\hline$\gamma$-Tocopherol & 10.3 & $1.1 \pm 0.1^{\mathrm{d}}$ & $2.3 \pm 0.1^{c}$ & $2.1 \pm 0.1^{c}$ & $6.8 \pm 0.1^{\mathrm{a}}$ & $4.4 \pm 0.1^{b}$ \\
\hline$\alpha$-Tocopherol & 12.0 & $9.4 \pm 0.2^{c}$ & $13.9 \pm 0.3^{a}$ & $4.4 \pm 0.3^{\mathrm{e}}$ & $10.2 \pm 0.2^{b}$ & $7.4 \pm 0.2^{\mathrm{d}}$ \\
\hline Total Ts & & $16.8 \pm 0.5^{f}$ & $23.1 \pm 0.6^{c}$ & $30.9 \pm 0.8^{a}$ & $24.4 \pm 0.5^{d}$ & $18.4 \pm 0.5^{\mathrm{e}}$ \\
\hline
\end{tabular}

Note: All measurements were done in triplicate $(n=3)$. Values with different superscripts within the same indices are significantly different $(p<0.05)$, one-way repeated ANOVA and Duncan's multiple range test. n.d., not detected; for tocopherols, only retention times (min.) are given in the table. 
Seventeen FAs in the form of methyl esters (FAMEs) were identified and quantified, among which the dominance of unsaturated fatty acids, mostly linoleic acid (from 43.0 to $57.8 \%$ ), followed by oleic acid (19.4-25.5\%), was found (Figure 1). Among the saturated fatty acids, representatives such as palmitic acid (8.7-13.0\%) were prevalent among the crab apple oils. Furthermore, similar concentrations of FAs were found in commercial pumpkin and soybean oils [19], where the concentration of linoleic, oleic, and palmitic acid among the FAs amounted to $47.1 \%, 34.1 \%$, and $10.7 \%$ and $50.8 \%, 24.6 \%$, and $10.2 \%$ of the total FAs, respectively. In addition, a similar distribution of FAs, in particular unsaturated fatty acids recovered from apple by-products, which represented $\sim 90 \%$ of the total fatty acids has been previously reported [20]. Whereas the opposite has been reported by Pires et al. [21], where the authors using the Soxhlet extraction indicated the dominance of palmitic acid, followed by stearic and linoleic acids (28.94\%, $16.4 \%$ and $15.8 \%$, respectively) in the oil of $M . \times$ domestica Borkh. cv. Bravo de Esmolfe apples.

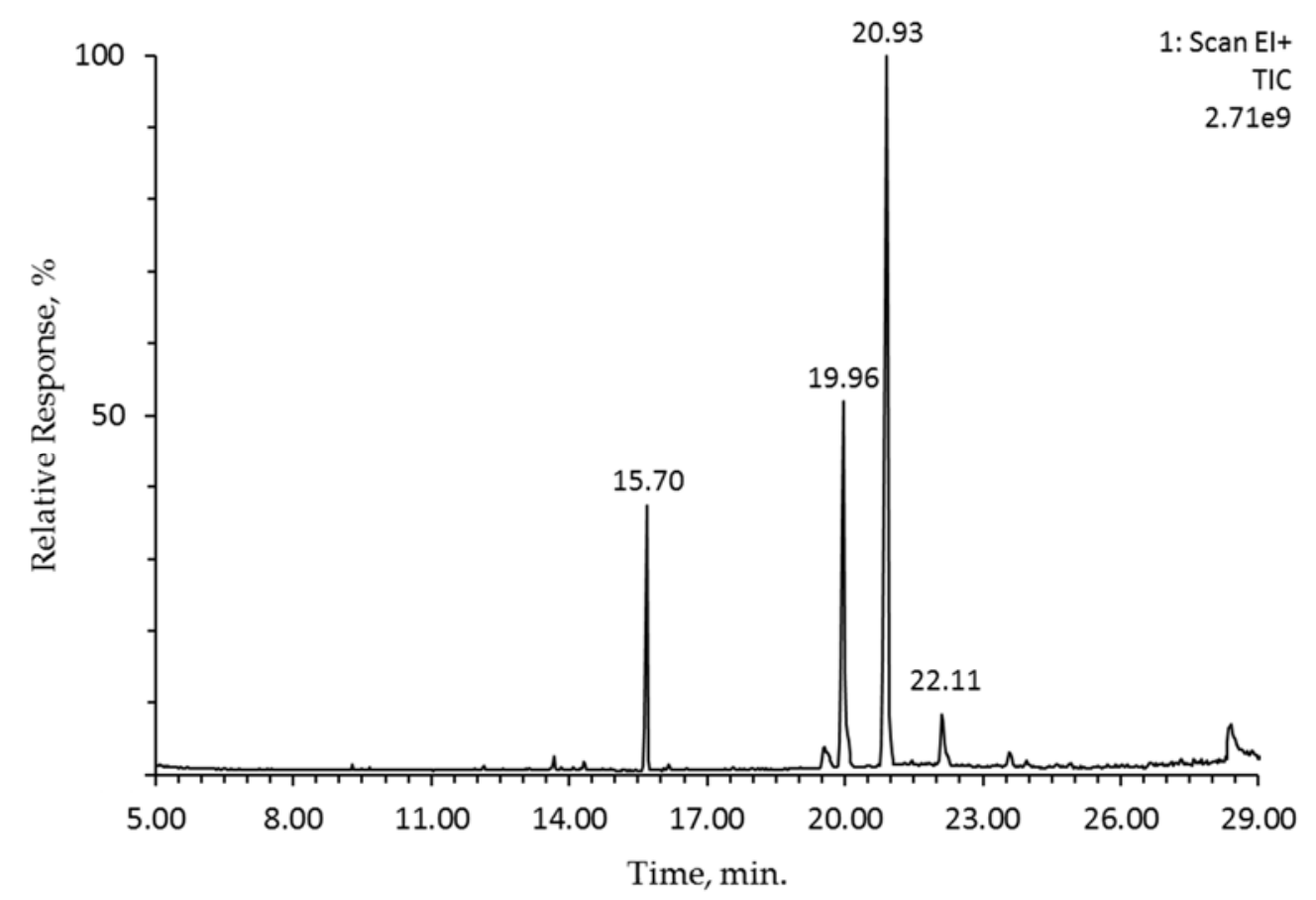

Figure 1. Chromatographic separation of FAMEs profile of crab apple Malus Bernu prieks oil using GC/MS: $15.70 \mathrm{~min}$ (palmitic acid), $19.96 \mathrm{~min}$ (oleic acid), $20.93 \mathrm{~min}$ (linoleic acid), and $22.11 \mathrm{~min}$ $(\alpha$-linolenic acid).

Considering the content of minor fatty acid molecules, $\alpha$-linolenic and arachidic acids were found to be dominant, varying in the range of $1.8-4.7 \%$ and $0.7-3.9 \%$, respectively. It must be noted, however, that the amounts of $\alpha$-linolenic acid reported here are significantly higher than those observed in Prunus avium kernel [22], M. bacata seed [12], Vitis spp. oils [23], and Viburnum opulus lipophilic extracts [24].

Only small amounts of less stable and therefore more prone to oxidation FFAs were found (Table 2). Among the FFAs analyzed, linoleic and oleic acid were found to be the dominant compounds in $M$. crab apples, varying in the ranges of $13.3-54.3 \%$ and $26.7-32.9 \%$, respectively. Considering the content of oxygenated fatty acids in oils, 9,10-dihydroxystearate was the only representative, and found in small amounts ( $<0.1 \%$ total lipids). This low amount may be due to the relatively high content of Ts responsible for protecting the oil against oxidation [25]. Among the aliphatic alcohols, nonacosan-10-ol was the dominant compound identified in all tested pomace oils, varying in the range of 78.8-90.0\%. The presence of nonacosan-10-ol as a typical constituent of the wax and cutin of Prunus avium and Malus $\times$ domestica Borkh. cv. "Red Fuji" was also described by Peschel et al. [26] and Dong et al. [27], respectively. 


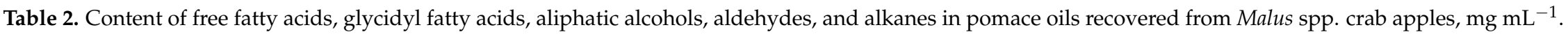

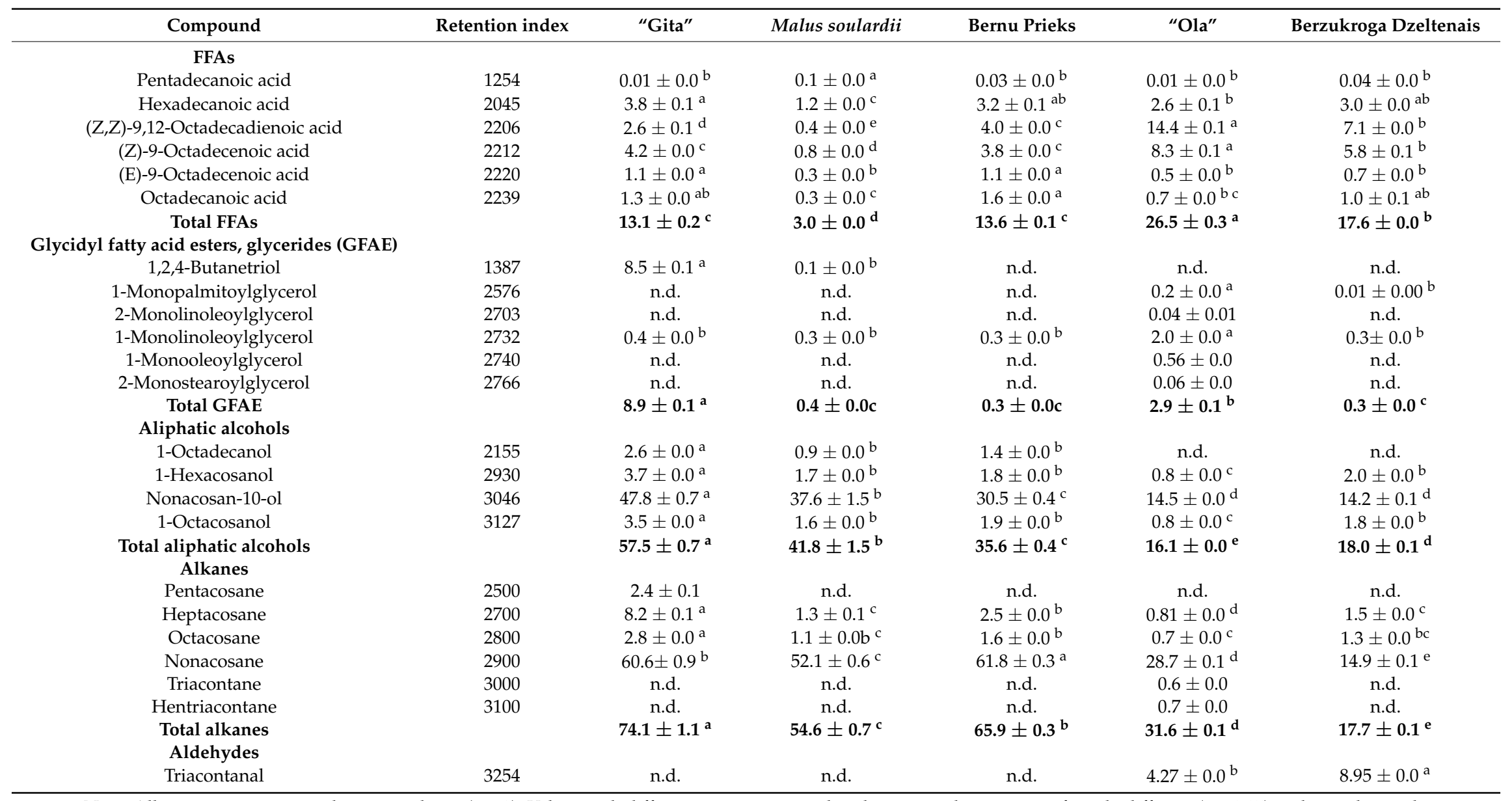

Note: All measurements were done in triplicate $(n=3)$. Values with different superscripts within the same indices are significantly different $(p<0.05)$. n.d., not detected. 
The results of the aforementioned study show that the oils recovered from by-products of Malus spp. especially cv. "Ola" are rich in fatty acids such as linoleic and oleic acids. A targeted utilization of apple pomace would facilitate management of dozens of by-products and benefit the environment and industry [6].

\subsection{Ts of Crab Apple Pomace Oil}

Tocochromanols are a group of the major forms of vitamin E, consisting primarily of four $(\alpha, \beta, \gamma$, and $\delta$ ) homologs of tocopherol and tocotrienol [9] that are synthesized exclusively by photosynthetic organisms and therefore could be ingested as part of the diet [28]. Vitamin E, is an essential lipid-soluble compound with a unique biological activity [29]. Four Ts $(\alpha, \beta, \gamma$, and $\delta)$ were identified and quantified in all crab and dessert apple pomace oils (Figure 2 and Table 1). With the exception of the $M$. Bernu prieks, $\alpha$-T was the prevailing homolog present in apple pomace oils, with the content in the range of 4.4-13.9 $\mathrm{mg} \mathrm{mL}^{-1}$ (percentage distribution of 14.1-60.0\%). The second abundant homolog, after $\alpha-\mathrm{T}$, was $\delta$-T with a percentage distribution of $13.5-70 \%$. A relatively high amount of $\delta$-T was found in $M$. Bernu prieks apples with a concentration of $21.5 \mathrm{mg} \mathrm{mL}^{-1}$. Moreover, this amount was 13.45- and 19.94-fold higher than reported earlier for Jatropha curcas L. and M. $\times$ domestica Borkh oil, respectively $[9,25]$.

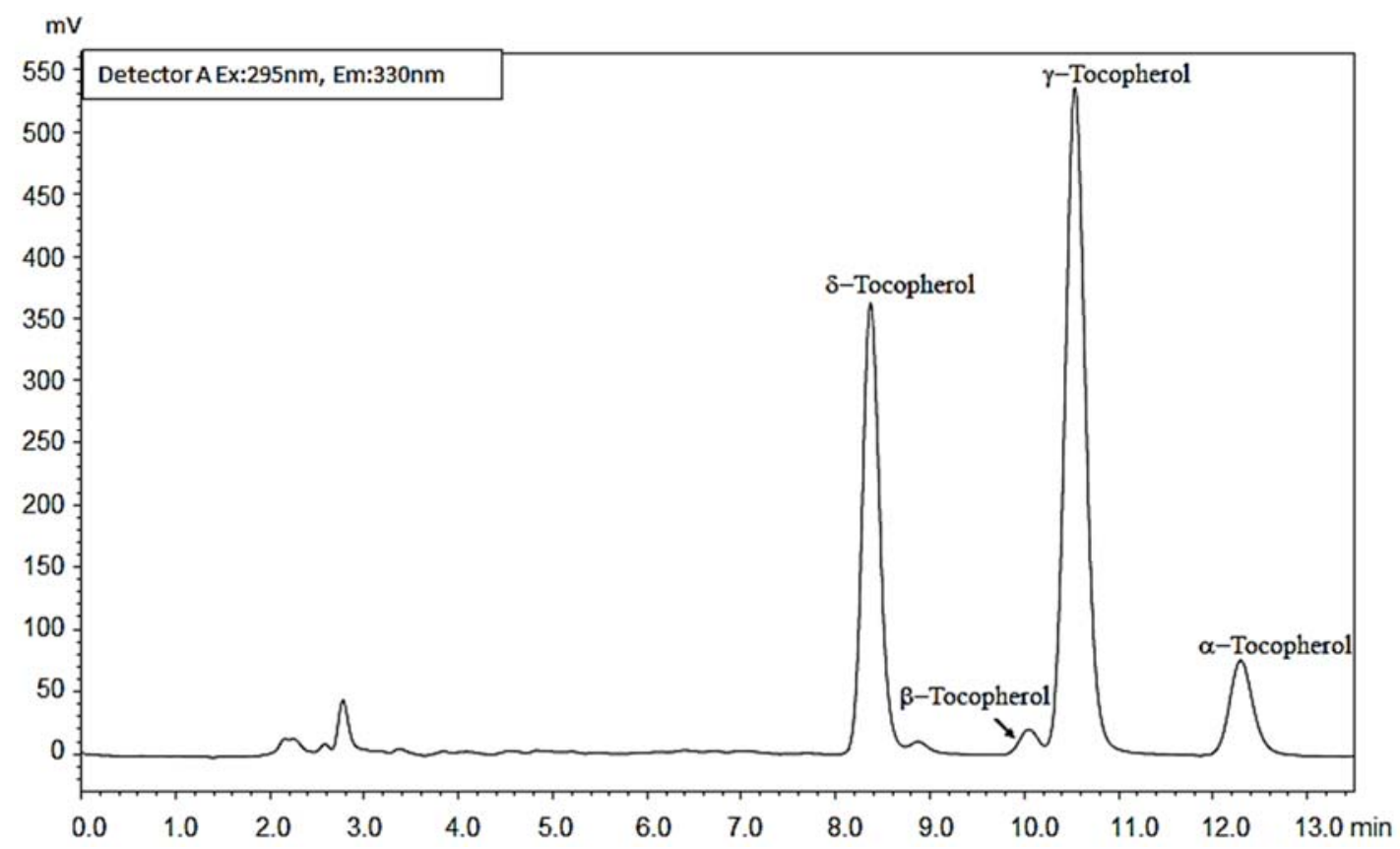

Figure 2. RP-HPLC/FLD chromatogram of tocopherols from Malus "Ola” oil separated using a Luna PFP column.

The first in vivo model assessing the antineoplastic activity of Ts has shown that $\delta$-tocopherol to be the most active homolog compared with $\alpha$ - or $\gamma$-T in inhibiting tumor growth, perhaps through trapping reactive oxygen and nitrogen species and inducing apoptosis [30]. The concentration of total Ts varied among the Malus species and dessert apples investigated, varying between 16.8 and $30.9 \mathrm{mg} \mathrm{mL}^{-1}$. The lowest content of total Ts was found in dessert apple pomace oil, while the highest value for M. Bernu prieks, followed by M. cv. "Ola", and M. $\times$ Soulardii. The calculated weight ratios of four Ts ( $\alpha$-T: $\beta$-T: $\gamma-\mathrm{T}: \delta$-T, average) in three crab and dessert apple pomace oils (excluding $M$. Bernu prieks) were 5.2:1.6:2.2:1.9 and 4.7:1.4:0.6:1.8, respectively. Having regard to the high content of $\delta$-T that has been found in the oil of $M$. Bernu prieks; the ratios were calculated individually for this sample, corresponding to 4.4:2.9:.2.1:21.5. Only a few studies have previously reported the presence of the Ts as constituents of crab and dessert apple seed oils $[9,18]$. The authors noted that the seed oils 
obtained from dessert apple seed oils were characterized by higher contents of Ts (19.1-37.9 $\mathrm{mg} \mathrm{mL}^{-1}$ oil) when compared to seed oils recovered from crab apples $\left(13.0-20.3 \mathrm{mg} \mathrm{mL}^{-1}\right)$. The average ratios of calculated amounts of Ts in crab and dessert apple seed oils were as follows: 4.1:2.7:1.6:1 and 2.6:2.5:1.1:1 [18]. The results of this study indicate a potential utilization of crab apple pomace as a natural and cheap source of vitamin E. Moreover, the results of this study might be useful for cosmetics companies specializing in the development/production of natural skin-care products.

\subsection{Phytosterols and Triterpenes of Crab Apple Pomace Oil}

Phytosterols are some of the compounds which are distributed among the tissues of plant [31]. A meta-analysis of 41 trials summarized in the excellent review article provided by Katan et al. [32] shows that intake of $2 \mathrm{~g} /$ day of stanols or sterols reduced low-density lipoprotein (LDL) by $10 \%$. Therefore, for the last decades, purified phytosterols have been added to numerous food products to enhance the functionality and increase the nutritional value [31]. The phytosterol and triterpene composition of the crab and dessert apple pomace oils analyzed are shown in Table 3.

Eleven biologically active compounds, five phytosterols (campesterol, stigmasterol, $\beta$-sitosterol, isofucosterol, and $\Delta 7$-avenasterol) and six triterpenes (squalene, $\alpha$-amyrin, lupeol, 24-methylenecycloartanol, uvaol, and ursolic aldehyde), were successfully identified and quantified in the tested pomace oils. $\beta$-Sitosterol was the prevalent compound found in all tested pomace oils with a percentage distribution of $10.3-94.5 \%$. The second dominant compound was campesterol, where the percentage distribution varied in the range $0.1-4.6 \%$. With regard to the $M$. Bernu prieks, stigmasterol was the prevailing phytosterol present in this sample, showing a content of $111.0 \mathrm{mg} \mathrm{mL}^{-1}$ oil $(87.8 \%)$, while in the other oil samples this compound was not found. The results of this study are in agreement with those published previously $[9,22,31]$, where the main phytosterol among the apple oils was $\beta$-sitosterol (94.0\%, 82.1\%, and 97.5\%, respectively). However, a minor difference in phytosterols profiles and ratios may be due to the different solvents used for the extraction of phytochemicals, as well as environmental factors and agricultural practices applied during the growing season.

Among the analyzed triterpenes, lupeol and uvaol were found to be dominant compounds of $M$. crab apples, varying in the range of $0.1-66.3 \%$ and $0.2-68.9 \%$, respectively. Recent reports indicate the presence of dietary lupeol as a constituent of vegetables and fruit including Brassica oleracea, Capsicum spp. Cucumis sativus, Solanum lycopersicum, and of fruits such as Olea spp. Ficus carica, Mangifera indica, Fragaria spp. and Vitis spp. [33,34], while uvaol in Prunus avium [26]. It must be noted, however, that the amounts of lupeol reported here are 99-, 16-, and 2-fold higher than reported earlier for olive fruit, aloe leaves, and ginseng oil, respectively [26]. The recent finding revealed that lupeol with no toxicity is a therapeutic and chemopreventive agent for the treatment of inflammation and cancer [33]. The same statement was proved by Siddique and Saleem [35], pointing out that lupeol is pharmacologically effective in treating various diseases under preclinical settings regardless of the type of administration. The results of this study suggest that the crab apple pomace oils of Malus spp., especially M. Berzukroga dzeltenais and M. cv. "Ola" to be considered as a good source of lupeol which could be incorporated as ingredients in making of high-value functional food products with many of physiological and biochemical effects. 
Table 3. Content of phytosterols and triterpenes in pomace oils recovered from Malus spp. crab apples, $\mathrm{mg} \mathrm{mL}^{-1}$.

\begin{tabular}{|c|c|c|c|c|c|c|}
\hline Compound & Retention Index & "Gita" & Malus soulardii & Bernu Prieks & “Ola" & Berzukroga Dzeltenais \\
\hline \multicolumn{7}{|l|}{ Phytosterols } \\
\hline Campesterol & 3230 & $1.4 \pm 0.0^{\mathrm{b}}$ & $2.5 \pm 0.6^{\mathrm{a}}$ & $0.1 \pm 0.0^{c}$ & $0.8 \pm 0.0^{c}$ & $1.7 \pm 0.0^{b}$ \\
\hline Stigmasterol & 3271 & n.d. & n.d. & $111.0 \pm 0.8^{\mathrm{a}}$ & $0.01 \pm 0.0^{b}$ & n.d. \\
\hline$\beta$-Sitosterol & 3341 & $73.2 \pm 0.5^{\mathrm{a}}$ & $51.5 \pm 0.9^{c}$ & $13.1 \pm 0.7^{\mathrm{e}}$ & $33.2 \pm 0.8^{\mathrm{d}}$ & $52.8 \pm 0.6^{\mathrm{b}}$ \\
\hline Isofucosterol & 3350 & $2.8 \pm 0.0^{\mathrm{a}}$ & $0.6 \pm 0.0^{c}$ & n.d. & $1.6 \pm 0.0^{\mathrm{b}}$ & $1.3 \pm 0.1^{\mathrm{b}}$ \\
\hline$\Delta 7$-Avenasterol & 3394 & n.d. & n.d. & $0.7 \pm 0.0$ & n.d. & n.d. \\
\hline Total sterols & & $77.4 \pm 0.5^{b}$ & $54.6 \pm 1.5^{d}$ & $126.1 \pm 1.5^{\mathrm{a}}$ & $35.6 \pm 0.8^{\mathrm{e}}$ & $55.8 \pm 0.7^{c}$ \\
\hline \multicolumn{7}{|l|}{ Triterpenes } \\
\hline Squalene & 2794 & n.d. & n.d. & $2.1 \pm 0.0^{\mathrm{a}}$ & $0.6 \pm 0.0^{b}$ & $1.3 \pm 0.0^{b}$ \\
\hline$\alpha$-Amyrin & 3378 & n.d. & $0.5 \pm 0.1^{\mathrm{b}}$ & $2.5 \pm 0.1^{\mathrm{a}}$ & n.d. & n.d. \\
\hline Lupeol & 3384 & $2.1 \pm 0.1^{b}$ & $0.05 \pm 0.0^{\mathrm{e}}$ & $0.2 \pm 0.0^{\mathrm{d}}$ & $1.3 \pm 0.1^{\mathrm{c}}$ & $3.0 \pm 0.1^{\mathrm{a}}$ \\
\hline 24-Methylenecycloartanol & 3437 & n.d. & n.d. & $1.4 \pm 0.0$ & n.d. & n.d. \\
\hline Uvaol & 3510 & $6.6 \pm 0.3^{a}$ & $0.1 \pm 0.0^{\mathrm{b}}$ & $0.7 \pm 0.0^{b}$ & $0.2 \pm 0.0^{b}$ & $0.2 \pm 0.0^{\mathrm{b}}$ \\
\hline Ursolic aldehyde & 3605 & $0.9 \pm 0.1^{b}$ & n.d. & $2.1 \pm 0.0^{\mathrm{a}}$ & $0.1 \pm 0.0^{b}$ & $0.02 \pm 0.0^{c}$ \\
\hline Total triterpenes & & $9.6 \pm 0.4^{a}$ & $0.7 \pm 0.0^{\mathrm{e}}$ & $5.3 \pm 0.1^{b}$ & $2.2 \pm 0.1^{\mathrm{d}}$ & $4.5 \pm 0.1^{c}$ \\
\hline Total carotenoids & & $6.4 \pm 0.5^{\mathrm{d}}$ & $12.8 \pm 0.7^{b}$ & $5.1 \pm 0.5^{c}$ & $5.4 \pm 0.5^{c}$ & $14.5 \pm 0.6^{a}$ \\
\hline $\mathrm{DPPH}^{\bullet}$ assay, mmol TAEC $\mathrm{mL}^{-1}$ & & $0.7 \pm 0.0^{\mathrm{c}}$ & $2.4 \pm 0.4^{\mathrm{a}}$ & $0.8 \pm 0.1^{b}$ & $0.5 \pm 0.0^{\mathrm{d}}$ & $0.7 \pm 0.0^{\mathrm{c}}$ \\
\hline FRAP assay, mmol TAEC $\mathrm{mL}^{-1}$ & & $1.1 \pm 0.4^{\mathrm{d}}$ & $1.0 \pm 0.2^{\mathrm{d}}$ & $2.2 \pm 0.2^{b}$ & $2.4 \pm 0.2^{\mathrm{a}}$ & $1.9 \pm 0.3^{c}$ \\
\hline
\end{tabular}

Note: All measurements were done in triplicate $(n=3)$. Values with different superscripts within the same indices are significantly different $(p<0.05)$. n.d., not detected. 


\subsection{Total Carotenoids of Crab Apple Pomace Oil}

While carotenoids are assumed to be present in dessert and crab apple, lemon, grape, mango, melon, and seed oils [31], there have been no reports on quantification specifically of crab apple pomace oils consisting of stems, seeds, flesh, and skin. The results show that the content of carotenoids was found higher in oil recovered from the pomace of yellow crab apple Berzukroga dzeltenais, while the lowest in oil extracted from the pomace of "Bernu prieks" apple, where the concentrations were 14.5 and $5.1 \mathrm{mg} \mathrm{mL}^{-1}$, respectively (Table 3). These results are in accordance with those of a previous study investigating different types of palm fruit oils for their carotenoid contents [36], and significantly higher than reported in quince and sunflower seed oils by Fromm et al. [37] Based on a report by Biesalski et al. [38], mean dietary intake required for beta-carotene to benefit from the preventive health potential are estimated to be $2-4 \mathrm{mg} /$ day, thus showing that between $\sim 0.2178$ and $\sim 0.4356 \mathrm{mg}$ per day of crab apple pomace oil would ensure the necessary recommended daily dose amount of beta-carotene.

\subsection{Antioxidant Activity of Crab Apple Pomace Oils}

The antioxidant activity of tested oils of Malus apple fruit was studied by radical scavenging capacity using the $\mathrm{DPPH}^{\bullet}$ method, while the ascertainment of total antioxidant capacity was done using the FRAP method. The $\mathrm{DPPH}^{\bullet}$ radical scavenging capacity of the apple pomace oils shows values ranging between 0.5 and $2.4 \mathrm{mmol}$ TAEC $\mathrm{mL}^{-1}$, with $M . \times$ soulardii having higher values, while crab apple M. cv. "Ola" having the lowest. Comparable results were reported by Prescha et al. [39] where flax (Linum usitatissimum) and rose hip (Rosa rugosa) oils were characterized as the strongest contributors to antioxidant activity using the $\mathrm{DPPH}^{\bullet}$ radicals. The results of scavenging capacity assay using the DPPH ${ }^{\bullet}$ radicals did not show correlation between the total bound FAs (FAMEs) $\left(\mathrm{R}^{2}=0.2191\right.$ ) (Figure $3 \mathrm{~A})$, Ts $\left(\mathrm{R}^{2}=0.0086\right)$ or carotenoids $\left(\mathrm{R}^{2}=0.2306\right)$ in apple pomace oils. In addition, a strong negative correlation was found between FFAs (silyl derivatives) and DPPH $\left(R^{2}=0.7206\right)$, while a moderate positive correlation was found between FFAs and DPPH values $\left(R^{2}=0.6581\right)$. The opposite results were obtained in a study by Tuberoso et al. [19], where the correlation between the total content of Ts in different commercial oils and scavenging of the $\mathrm{DPPH}^{\bullet}$ radical was $\mathrm{R}^{2}=0.7000$. The data from FRAP assay were significantly different $(p<0.05)$ and no correlation was found with the DPPH ${ }^{\bullet}$. The results showed that the oil recovered from $M . \mathrm{cv}$. "Ola" is more active compared with other oils. Generally, the only positive and strong correlation $\left(R^{2}=0.8732\right)$ was found between the bound FAs and FRAP (Figure 3B).
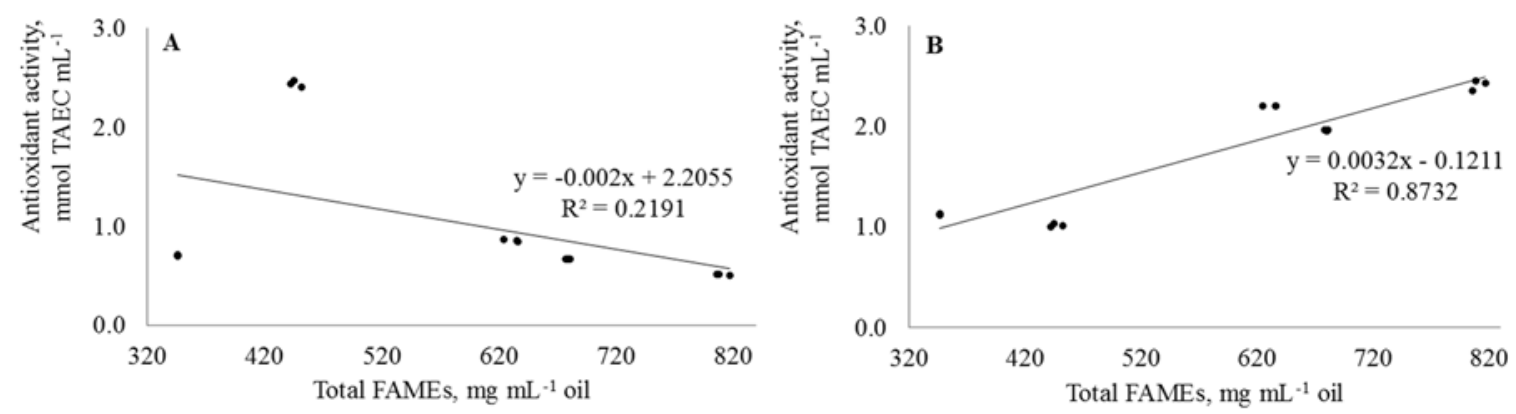

Figure 3. Correlation between total FAMEs $\left(\mathrm{mg} \mathrm{mL}^{-1}\right.$ oil) and the antioxidant activities (mmol TAEC $\mathrm{mL}^{-1}$ ) of tested apple pomace oils using: DPPH ${ }^{\bullet}$ assay (A); and FRAP assay (B).

The results of this study show that the different constituents, as well as testing systems, may affect the capacity of oils to quench different radicals. A similar result was reported previously by Wang et al. [40], pointing out that some compounds, which have ABTS radicals scavenging activity, do not show $\mathrm{DPPH}^{\bullet}$ activity. Moreover, Radenkovs et al. [41] proposed that radical scavenging $\left(\mathrm{DPPH}^{\bullet}\right)$ with each compound is an independent process, the overall success of which depends 
predominantly on the chemical structure of a particular biologically active compound, rather than on the concentration.

\subsection{Antimicrobial Activity of Crab Apple Pomace Oils}

MIC is defined as the lowest concentration of an antimicrobial mean that will suppress the visible growth of a microorganism after overnight incubation [42]. In this study, the susceptibility of standard Gram-positive and Gram-negative test bacteria to pomace oils obtained from Malus spp. crab apple was estimated in vitro using the method recommended by Balouiri et al. [43]. MIC data are presented in Table 4.

Table 4. Minimal inhibitory concentration values of the five Malus spp. pomace oils against five reference test cultures, $\mathrm{mg} \mathrm{mL}^{-1 *}$.

\begin{tabular}{cccccc}
\hline Species & “Gita" & Malus soulardii & Bernu Prieks & “Ola” & Berzukroga Dzeltenais \\
\hline Staphylococcus aureus & 62.5 & 62.5 & 62.5 & $\mathbf{3 1 . 2}$ & 62.5 \\
Streptococcus pyogenes & 62.5 & 62.5 & 62.5 & 62.5 & 62.5 \\
Enterococcus faecalis & 62.5 & 62.5 & 62.5 & 62.5 & 62.5 \\
Pseudomonas aeruginosa & 62.5 & 62.5 & 62.5 & $\mathbf{3 1 . 2}$ & $\mathbf{3 1 . 2}$ \\
Escherichia coli & 62.5 & 62.5 & $\mathbf{3 1 . 2}$ & $\mathbf{3 1 . 2}$ & $\mathbf{3 1 . 2}$ \\
\hline
\end{tabular}

* Gentamicin was employed as positive control. The MIC to gentamicin was $0.004 \mathrm{mg} \mathrm{mL}^{-1}$ in all experiments.

The growth of Gram-positive test bacteria was inhibited only at the highest oil concentrations applied (MIC 125.0 and $61.2 \mathrm{mg} \mathrm{mL}{ }^{-1}$ ) for M. $\times$ domestica Borkh. cv. "Gita", M. $\times$ soulardii, and $M$. Bernu prieks. However, the pomace oil of $M$. cv. "Ola" had a MIC value of $31.2 \mathrm{mg} \mathrm{mL}^{-1}$ for Gram-positive Staphylococcus aureus. Different activities of the tested pomace oils towards Gram-negative test bacteria was observed. The pomace oil of $M$. Bernu prieks, M. cv. "Ola", and M. Berzukroga dzeltenais exhibited an inhibitory activity with MIC value $31.2 \mathrm{mg} \mathrm{mL}^{-1}$ against $E$. coli, while only pomace oil of M. cv. "Ola" and M. Berzukroga dzeltenais were able to suppress the growth of $P$. aeruginosa at a concentration of $31.2 \mathrm{mg} \mathrm{mL}^{-1}$. Our data show that tested pomace oils of $M$. spp. had differing antimicrobial activity against bacteria. Only the pomace oil of $M$. cv. "Ola" showed an inhibition of both Gram-positive and Gram-negative test cultures, while, to a lesser extent, the $M$. Berzukroga dzeltenais pomace oil had the ability to inhibit only Gram-negative pathogenic bacteria.

In contrast to our data, some reports have shown significantly better susceptibility of pathogenic bacteria to antimicrobial agents recovered from different plant extracts, however these utilized different inoculum concentrations (in particular $10^{5} \mathrm{CFU} \mathrm{mL}^{-1}$ ) [44]. It was proposed previously that increasing the inoculum concentration from $10^{5}$ to $\geq 10^{8} \mathrm{CFU} \mathrm{mL} \mathrm{m}^{-1}$ may cause a reduction in bactericidal activity of all the antimicrobial compounds against pathogenic bacteria [45]. The results of this approach show that the growth of pathogenic bacteria probably was influenced by the chemical composition of pomace oils, particularly linoleic and oleic acids [46], which were found to be dominant representatives of pomace oils from M. cv. "Ola", and M. Berzukroga dzeltenais. Further in-depth research on evaluation of antimicrobial activity of lipophilic individual isolates from Malus spp. is highly recommended.

\section{Materials and Methods}

\subsection{Plant Material}

Crab apple fruit of Malus species (M. × soulardii, M. Bernu prieks, M. "Ola”, M. Berzukroga dzeltenais) were collected in Pūre Horticultural Research Centre Ltd. (Pūre parish, Tukums District, Latvia), GPS location: N: $57^{\circ} 02^{\prime} 23.30^{\prime \prime}$; E: $22^{\circ} 54^{\prime} 48.1^{\prime \prime}$, on 26 September, 2017 (Table S1). Dessert apples of cv. "Gita" (as a reference for comparison) were harvested in Institute of Horticulture (Dobele, Latvia), GPS location: N: $56^{\circ} 36^{\prime} 35.0^{\prime \prime}$; E: $23^{\circ} 17^{\prime} 58.7^{\prime \prime}$ on 13 September 2017 (starch-iodine test-4.8 points from total 10). The ripening stage of "Gita" fruit was assessed using a starch-iodine test [47], while crab apples were harvested at $\sim 121$ days after full bloom. The apple trees were cultivated in soils, varying 
from haplic luvisol (super eutric) to luvisol (hypereutric), while the soil texture, varying from poorly podzolic sandy loam to loamy soil. The integrated growing system and a planting distance of $3 \mathrm{~m} \times 4 \mathrm{~m}$ for crab apple trees and $5 \mathrm{~m} \times 3 \mathrm{~m}$ for "Gita" apple trees, without irrigation system was used. Grass was mowed several times $(\sim 6)$ during the growing season and the rows were treated with herbicides in the initial part of the vegetation season. Cultivar "Gita" apple trees were grafted on the rootstock B9 and grown in the orchard according to the integrated system using the same conditions. Crab apple fruit were picked from 10 randomly selected eight-year-old trees, while "Gita" fruit were picked from 10 randomly selected seven-year-old trees. About $0.7 \pm 0.1 \mathrm{~kg}$ of each crab and 1.5 kg of dessert apple fruit were harvested (between 11:00 and 15:00 local time) and transported immediately (within $1 \mathrm{~h}$ ) to the laboratory of the Institute of Horticulture. All apple fruit were carefully mixed, frozen in a freezer "PORKKA BF 710" (Porkka, Lahti, Finland) at $-25 \pm 1{ }^{\circ} \mathrm{C}$. Frozen fruits were packed in polypropylene bags (1-1.5 kg in each) and stored in a low-temperature chamber "VTK $201 \mathrm{~V}$ " (Holod-MSK, Moscow, Russia) at $-18 \pm 1{ }^{\circ} \mathrm{C}$ until analysis, a maximum of 10 weeks. The juice from apple fruit was obtained (after frozen fruit were thawed to ambient temperature $-22 \pm 1^{\circ} \mathrm{C}$ ) using a Voran $60 \mathrm{~K}$ basket press at a pressure of 300 bars (Voran Maschinen $\mathrm{GmbH}$, Pichl bei Wels, Austria). Pomace (consisting of stems, seeds, flesh, skin) after juice pressing were gradually freeze-dried using a FreeZone freeze-dry system (Labconco, Kansas City, MO, USA) at $-51 \pm 1{ }^{\circ} \mathrm{C}$ under vacuum of 0.055-0.065 mbar for $20 \mathrm{~h}$, further milled $(0.5 \mathrm{~mm}$ particle size) using a variable speed rotor mill Pulverisette 14 (Fritsch, Idar-Oberstein, Germany). The moisture content of samples was measured gravimetrically at $103 \pm 2{ }^{\circ} \mathrm{C}$ using the method of Ruiz [48]. Samples intended for the analysis of fatty acid methyl esters (FAMEs), free fatty acids (FFAs) and phytosterols were packed into Mylar bags (foil Mylar zip-lock bags, thickness $3 \mathrm{~mm}$, New York, NY, USA), frozen $\left(-18^{\circ} \mathrm{C}\right)$ and delivered directly to the laboratory of the University of Latvia, Riga, Latvia.

\subsection{Chemicals and Standards}

Standards of $\alpha, \beta, \gamma$, and $\delta$ homologs of tocopherol (T) (purity $>95 \%$ ) were purchased from Merck Millipore (Darmstadt, Germany). Methyl heptadecanoic acid (analytical standard, purity $\geq 99 \%$ ), $\gamma$-linoleic acid (analytical standard, purity $\geq 99 \%$ ), dodecanal (analytical standard, purity $\geq 98 \%$ ), 1-octadecanol (ReagentPlus, purity $\geq 99 \%$ ), n-tetracosane (analytical standard, purity $\geq 99.5 \%$ ), and ergosterol (pharmaceutical secondary standard, purity 95\%) were purchased from Sigma-Aldrich Chemie $\mathrm{GmbH}$ (Schnelldorf, Germany), while n-paraffin analytical standard $\left(\mathrm{C}_{8}-\mathrm{C}_{40}\right.$ alkanes calibration standard) was obtained from Supelco Analytical (Bellefonte, PA, USA). HPLC grade pyridine was purchased from Honeywell Riedel-de Haën $\mathrm{GmbH}$, (Seelze, Germany), HPLC grade methanol, n-hexane, petroleum ether (puriss. p.a., $\geq 99.9 \%$, boiling point $50-70{ }^{\circ} \mathrm{C}$ ), bis(trimethylsilyl) trifluoroacetamide (BSTFA) and boron trifluoride-methanol solution $\left(\mathrm{BF}_{3} / \mathrm{MeOH}\right)$ were purchased from Sigma-Aldrich Chemie Ltd., (St. Louis, MO, USA). The 2.2-diphenyl-1-picrylhydrazyl, 2-propanol (HPLC grade), resazurin sodium salt were obtained from Sigma-Aldrich Chemie GmbH (Steinheim, Germany). Deionized water was prepared using an Elix Advantage 3 water purification system (Millipore S.A.S., Molsheim, France).

\subsection{Soxhlet Extraction}

Soxhlet extraction was done using the method of Abdolshahi et al. [49] with slight modification. Triplicate samples about of $10 \mathrm{~g}$ of freeze-dried and finely ground pomace were accurately weighted in extraction thimbles (Whatman single thickness, $33 \times 94 \mathrm{~mm}$ ). Further, the thimbles placed inside the extraction chambers and submitted to a Soxhlet extraction using the system B-811 (BÜCHI Labortechnik AG, Flawil, Switzerland), which is fully automated. The samples were extracted using $100 \mathrm{~mL}$ of petroleum ether for $3 \mathrm{~h}$. Sufficient heat (Soxhlet warm extraction at $70^{\circ} \mathrm{C}$ ) was used to give about 10 cycles of solvent per $\mathrm{h}$. At the end of the extraction, oil samples were dried to release the solvent from oil extracts (using the above-mentioned Soxhlet system), further Soxhlet beakers were placed in a desiccator to cool and weighted to determine the yield of crude oil. Oil samples were transferred to 
$15 \mathrm{~mL}$ plastic tubes (Sarstedt AG \& Co. KG, Nümbrecht, Germany) and stored at $-18 \pm 1{ }^{\circ} \mathrm{C}$ until analysis, a maximum of two weeks.

\subsection{Preparation of FAs for GC/MS Analysis}

Methylation of polyfunctional compounds in oil samples was carried out using the method of Lelacheur et al. [50] with slight modification. Briefly, $0.25 \mu \mathrm{L}$ of $14 \% \mathrm{BF}_{3} / \mathrm{MeOH}$ was added to each $0.1 \mathrm{~mL}$ oil sample in $22 \mathrm{~mL}$ glass vials (PerkinElmer, Waltham, MA, USA) and heated for a minimum of $1 \mathrm{~h}$ at $70{ }^{\circ} \mathrm{C}$. Tubes were then allowed to cool for approximately $20 \mathrm{~min}$. When tubes reached ambient temperature, $3.0 \mathrm{~mL}$ of double distilled water (DDW) and $3.0 \mathrm{~mL}$ of $\mathrm{n}$-hexane were added to each tube followed by vortex-mixing for $15 \mathrm{~s}$. After centrifugation at $3200 \times \mathrm{g}$ for $4 \mathrm{~min}$, the upper $\mathrm{n}$-hexane layer was quantitatively transferred to a $15 \mathrm{~mL}$ plastic tube. Each sample was extracted thrice using the above-mentioned procedure. The supernatant fractions were hereafter flushed with nitrogen for $\sim 5 \mathrm{~min}$ and dry residues stored in a low-temperature chamber "VTK $201 \mathrm{~V}$ " (Holod-MSK, Moscow, Russia) at $-18 \pm 1{ }^{\circ} \mathrm{C}$ until analysis, a maximum of two weeks. Directly prior to GC/MS analysis, a $0.1 \mathrm{~g}$ of each oil sample (FAMEs) was reconstituted with $1 \mathrm{~mL}$ of pyridine.

\subsection{GC Conditions for FAMEs}

The analysis of FAMEs was carried out on a Clarus 580 system PerkinElmer, Inc. (Waltham, MA, USA) equipped with a quadrupole analyzer Clarus SQ 8 C mass-selective detector (Waltham, MA, USA). All analyses of FAMEs were done using Omegawax 250 (Sigma-Aldrich Chemie $\mathrm{GmbH}$, Taufkirchen, Germany) column with a stationary phase of intermediate polarity $(30 \mathrm{~m} \times 0.25 \mathrm{~mm}$, sorbent thickness- $0.25 \mu \mathrm{m})$. The injector temperature has been set to $+280{ }^{\circ} \mathrm{C}$; automatic injection using an autosampler, injection volume $0.5 \mu \mathrm{L}$; split ration $4: 1$. The initial oven temperature was maintained at $75{ }^{\circ} \mathrm{C}$ for $2 \mathrm{~min}$, then raised to $150{ }^{\circ} \mathrm{C}$ (rate of $20{ }^{\circ} \mathrm{C} \mathrm{min}{ }^{-1}$ ), then increased to $270{ }^{\circ} \mathrm{C}$ (rate of $4{ }^{\circ} \mathrm{C} \mathrm{min}{ }^{-1}$ ). Helium (ultra-high purity 5.0 grade- $99.999 \%$ ) was used as a carrier gas at the initial flow rate of $2.0 \mathrm{~min}^{-1}$ and then held constant at $1.0 \mathrm{~min}^{-1}$ with the split ratio 4:1. The total separation time was $35.75 \mathrm{~min}$.

\subsection{GC Conditions for FFAs, Phytosterols, and Triterpenes}

After silylation using the method of Lelacheur et al. [50], oils were analyzed using the above-mentioned GC system. All analyses of the silylated derivatives were done using an Elite-5MS capillary column $(30 \mathrm{~m} \times 0.25 \mathrm{~mm}$ i.d. and film thickness of $0.25 \mu \mathrm{m}$, PerkinElmer, Waltham, MA, USA). The injector temperature was set to $+290{ }^{\circ} \mathrm{C}$; automatic injection using an autosampler, injection volume $1.0 \mu \mathrm{L}$; split ratio 4:1. The initial oven temperature was maintained at $75{ }^{\circ} \mathrm{C}$ for $2 \mathrm{~min}$, then raised to $130{ }^{\circ} \mathrm{C}$ (rate of $20{ }^{\circ} \mathrm{C} \mathrm{min}-1$ ), and after at a rate of $4{ }^{\circ} \mathrm{C} \mathrm{min}{ }^{-1}$ increased to $310^{\circ} \mathrm{C}$, followed by an isothermal operation for $5 \mathrm{~min}$. Helium (ultra-high purity 5.0 grade- $99.999 \%$ ) was used as a carrier gas at the initial flow rate of $2.0 \mathrm{~min}^{-1}$ for $0.5 \mathrm{~min}^{-1}$, and then followed by a constant flow at $1.0 \mathrm{~min}^{-1}$. The total separation time was $54.75 \mathrm{~min}$.

\subsection{The MS Conditions for FAMEs and Silyl Derivatives Detection}

Detector mode: Electron impact ionization was at $70 \mathrm{eV}$; ion source temperature: $+230{ }^{\circ} \mathrm{C}$; inlet temperature was +290 and $280{ }^{\circ} \mathrm{C}$ for silyl and FAMEs derivatives, respectively; capture time for FAMEs starting from $3.5 \mathrm{~min}\left(1.7 \mathrm{scan} \mathrm{s}^{-1}\right)$, while from $0.5 \mathrm{~min}\left(0.50 \mathrm{scan} \mathrm{s}^{-1}\right)$ for silyl derivatives; ion multiplier: $1700 \mathrm{~V}$; and ion $\mathrm{m} / \mathrm{z}$ interval: $42-550$ for FAMEs and 35-750 for silyl derivatives.

\subsection{Standard Compounds Used for Calibration}

Methyl heptadecanoic acid for FAMEs, $\gamma$-linoleic acid for FFAs and glycidyl fatty acid esters, 1-octadecanol for aliphatic alcohols, dodecanal for aldehydes, n-tetracosane for alkanes, and ergosterol for phytosterols and triterpenes. Least squares regression analysis was implemented, 
using the peak area ratios against increasing standard concentrations to obtain calibration linearity $(y=a x+b$, where $b$ is gradient of the slope and $a$ is intercept point at $y$-axis (i.e., when $x=0)$ (Table S2). The precision of the method was assessed by triplicate analysis of standard solutions at five concentrations.

Retention indexes (RI) for temperature programmed GC analysis at a constant heating rate were calculated using the method of van Den Dool and Kratz [51] based on n-paraffin $\left(\mathrm{C}_{8}-\mathrm{C}_{40}\right)$ standard mixture. The components were identified by comparison of their RI and mass spectral data using an in-house built library and the NIST mass spectral library NIST MS 2.2.

\subsection{Tocopherol Determination Using the RP-HPLC/FLD}

Tocopherols (Ts) were determined using the previously validated method of Górnaś et al. [52]. Crab and dessert apple pomace oils $(0.1 \mathrm{~g})$ were diluted in 2-propanol to a volume of $10 \mathrm{~mL}$ and filtered through an $\mathrm{MS}^{\circledR}$ nylon syringe filter with $0.22 \mu \mathrm{m}$ pore size (Membrane Solutions, Plano, TX, USA) into $1.5 \mathrm{~mL}$ glass vials and immediately analyzed using the HPLC system. The chromatographic separation was carried out using the Shimadzu HPLC system (Shimadzu Corporation, Kyoto, Japan) consisting of a pump (LC-10ADvp), a degasser (DGU-14A), a low-pressure gradient unit (FCV-10ALvp), a system controller (SCL-10Avp), an auto injector (SIL-10AF), a column oven (CTO-10ASvp), a fluorescence detector (RF-10AXL) and a Luna PFP column $(3 \mu \mathrm{m}, 150 \times 4.6 \mathrm{~mm})$ with a guard column $(4 \mathrm{~mm} \times 3 \mathrm{~mm})$ (Phenomenex, Torrance, CA, USA). The analysis was done using the following conditions: mobile phase methanol:water (93:7; v/v); flow $\left(1.0 \mathrm{~mL} \mathrm{~min}^{-1}\right)$; and column oven temperature $\left(40^{\circ} \mathrm{C}\right)$. The total separation time was $13.0 \mathrm{~min}$. The identification and quantification of each of tocochromanols homolog was estimated using a fluorescence detector at an excitation wavelength of $295 \mathrm{~nm}$ and emission wavelength of $330 \mathrm{~nm}$.

\subsection{Spectrophotometric Analysis of the Total Carotenoids}

Total carotenoids were estimated using the method of Biehler et al. [53] As reported, the spectrophotometric method (method of mean) is robust with high reproducibility, sensitivity, and strong correlation with the HPLC method. The method is based on the mean absorption coefficients and mean absorption wavelength (Figure 4).
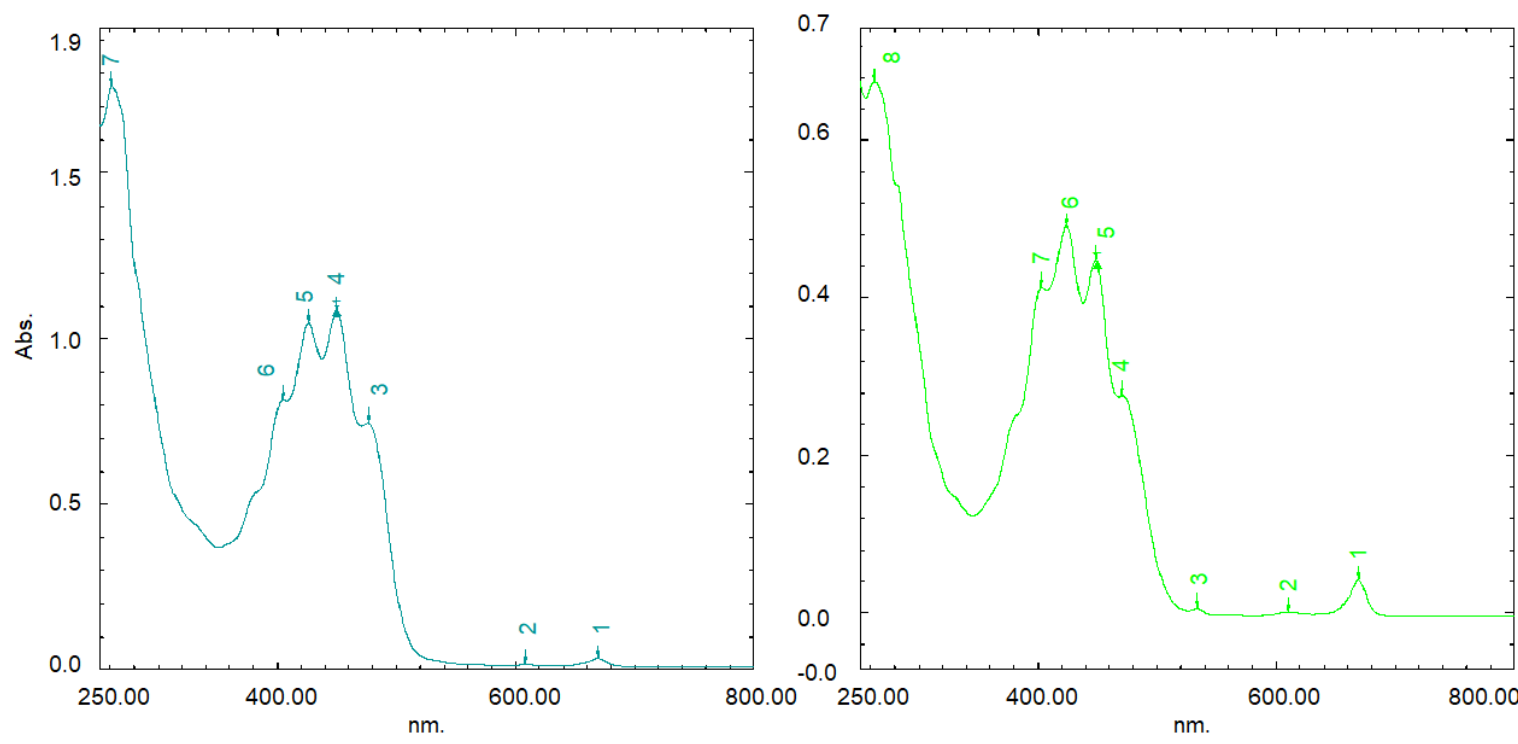

Figure 4. The typical UV-VIS spectrum of carotenoid interference between 390 and $480 \mathrm{~nm}$.

Humans typically consume a wide variety of carotenoids in the diet; $\beta$-carotene, along with lycopene, lutein, zeaxanthin, $\beta$-cryptoxanthin, and $\alpha$-carotene, account for $90 \%$ of circulating 
carotenoids [54]. Therefore, considering exclusively these major abundant carotenoids, an average absorption coefficient is equivalent to $\varepsilon=135,310$.

To estimate the average carotenoid concentrations $\left(\mathrm{mol} \mathrm{L}^{-1}\right)$, the following equation was used:

$$
c\left(\mathrm{~mol} \mathrm{~L}^{-1}\right)=\frac{A_{450 \times} F_{d}}{135,310}
$$

with $\mathrm{A}_{450}$ being the mean absorbance maximum (A450), $\mathrm{d}=1 \mathrm{~cm}$, and $\mathrm{F}$ a dilution factor adjusting for extractions, drying, and reconstitution processes. Using an average molar mass $\left(\mathrm{g} \mathrm{mol}^{-1}\right)$, results can also be expressed as $\mathrm{g}$ per $\mathrm{L}^{-1}$ and as $\mathrm{mg}$ per $100 \mathrm{~g}^{-1}$.

A $0.1 \mathrm{~g}$ oil sample was 10 times diluted using petroleum ether in centrifuge tubes $(15 \mathrm{~mL})$, and the absorbance was measured immediately at $450 \mathrm{~nm}$ using a UV-1800-Visible Spectrophotometer SHIMADZU (Shimadzu Corp., Kyoto, Japan). Results were expressed as mg $\beta$-carotene equivalent per $\mathrm{mL}^{-1}\left(\mathrm{mg} \mathrm{mL}^{-1}\right)$.

\subsection{Antioxidant Assays}

\subsubsection{DPPH ${ }^{\bullet}$ Radical Scavenging Activity}

The radical scavenging activity, using the free-radical $\mathrm{DPPH}^{\bullet}$ assay was determined using the method of Li et al. [55] with slight modification. Briefly, the oils $(100 \mu \mathrm{L})$ were reacted with $2.9 \mathrm{~mL}$ of $\mathrm{DPPH}^{\bullet}$ solution (0.0039 $\mathrm{g} \mathrm{DPPH}^{\bullet}$ in $100 \mathrm{~mL}$ methanol). Absorbance of the oil extracts was done at $515 \mathrm{~nm}$ using a spectrophotometer. The absorbance results were converted using a calibration curve of the standard and expressed as mmol Trolox equivalent antioxidant capacity per $\mathrm{mL}^{-1}$ of oil $\left(\mathrm{mmol}\right.$ TEAC $\left.\mathrm{mL}^{-1}\right)$.

\subsubsection{The Ferric Reducing Antioxidant Power (FRAP) Assay}

Free reducing antioxidant power (FRAP) was determined using the method of Radenkovs et al. [41]. The FRAP reagent was prepared daily from $300 \mathrm{~mL}$ sodium acetate buffer (0.3 mol L-1; pH 3.6), 2,4,6-tripyridyl-s-triazine (TPTZ) solution in $40 \mathrm{mmol} \mathrm{L}^{-1}$ of $\mathrm{HCl}$ and $\mathrm{FeCl}_{3}\left(20 \mathrm{mmol} \mathrm{L}^{-1}\right)$. The three solutions were mixed together at the ratio of 10:1:1 $(\mathrm{v} / \mathrm{v} / \mathrm{v})$, respectively, and then warmed to $37^{\circ} \mathrm{C}$. Extracts and standard $\left(\mathrm{FeSO}_{4} \cdot 7 \mathrm{H}_{2} \mathrm{O}\right)$ or double distilled water (DDW) for blanks $(100 \mu \mathrm{L})$ were mixed with FRAP reagent $(3.6 \mathrm{~mL})$. The change in absorbance from red to blue was followed at $593 \mathrm{~nm}$ after $10 \mathrm{~min}$. A Trolox calibration curve was done between 0.1 and $1.0 \mathrm{mg} \mathrm{mL}^{-1}$. The absorbance results were converted using a calibration curve of the standard and expressed as mmol Trolox equivalent antioxidant capacity per $\mathrm{mL}^{-1}$ of oil (mmol TEAC $\mathrm{mL}^{-1}$ ).

\subsection{Minimum Inhibitory Concentration (MIC) Determination}

The minimum inhibitory concentration (MIC) was determined using the microdilution method in 96-well plates [43]. Five standard strains of test microorganisms were used for antimicrobial sensitivity testing included Gram-positive and Gram-negative bacteria (Pseudomonas aeruginosa ATCC10145; E. coli ATCC25922; Enterococcus faecalis ATCC29212; Streptococcus pyogenes ATCC19615; and Staphylococcus aureus ATCC65388/NCTC7447). Bacteria were grown on Nutrient agar (NA, Oxoid, CM0003, ThermoFisher Scientific, Hampshire, UK) at $37^{\circ} \mathrm{C}$ for $20-24 \mathrm{~h}$.

Prior to analysis, the microorganism colonies were suspended in Mueller Hilton broth (MHB, Ref. 4017412, Biolife, Milano, Italy) and the suspension was adjusted using the DEN-1B McFarland Tube Densitometer (Grant Instruments Ltd., Cambridge, United Kingdom), to the final turbidity of $0.5 \mathrm{McF}$ arland units which corresponds to $10^{8} \mathrm{CFU} \mathrm{mL}^{-1}$ [43]. Under aseptic conditions, the tested oils were solubilized in $50 \%(v / v)$ of dimethyl sulfoxide (DMSO) (Merck Millipore, Darmstadt, Germany) in DDW in the range from 0.9 to $125.0 \mathrm{mg} \mathrm{mL}^{-1}$. The negative control consisted of DMSO, MHB, and test cultures. For the broth microdilution test, $100 \mu \mathrm{L}$ of each bacterial suspension in broth medium was added in each well already containing $100 \mu \mathrm{L}$ of two-fold serially diluted plant extract. The final 
volume in each well was $300 \mu \mathrm{L}$. Viability of the bacterial cell was visualized using $30 \mu \mathrm{L} /$ well of $0.01 \%$ resazurin aqueous solution. The plates were incubated at $37 \pm 1^{\circ} \mathrm{C}$ for $24 \mathrm{~h}$. The MIC values were identified as the lowest concentration in which no viable bacterial were observed.

\subsection{Statistical Analysis}

The results obtained are shown as means \pm standard error of the mean from three replicates $(n=3)$. The $p$-value $<0.05$ was used to denote significant differences between mean values determined using one-way analysis of variance (ANOVA) and the Duncan's multiple range test done using the assistance of IBM ${ }^{\circledR}$ SPSS $^{\circledR}$ Statistics program 20.0 (SPSS Inc., Chicago, IL, USA).

\section{Conclusions}

The majority of the identified fatty acids in the oils recovered from by-products of Malus spp. were found in bound forms, in the form of di- and triglycerides, and fatty acid alkyl esters (from 446.5 to $810.4 \mathrm{mg} \mathrm{mL}^{-1}$ ). Only small amounts of less stable free fatty acids were found, varying in the range of 3.0-26.5 mg mL ${ }^{-1}$. The oils recovered from by-products of Malus spp., especially M. Bernu prieks, followed by M. cv. "Ola", and M. $\times$ Soulardii are rich in Ts. A relatively high amount of $\delta-T$ was found in $M$. Bernu prieks apples with a concentration of $21.5 \mathrm{mg} \mathrm{mL}^{-1}$. This amount was 13.45- and 19.94-fold higher than reported earlier for Jatropha curcas L. and M. $\times$ domestica Borkh oil, respectively. In total, 11 compounds including five phytosterols and six triterpenes were identified and quantified in the tested pomace oils. $\beta$-Sitosterol was the prevalent compound found in all tested pomace oils with a percentage distribution of $10.3-94.5 \%$. Among the analyzed triterpenes, lupeol was found to be the dominant compounds in $M$. crab apples, varying in the range of $0.1-66.3 \%$. Thus far, this is the first report providing the evidence on the presence of dietary lupeol in the $M$. crab apples. Moreover, the amount of lupeol reported here are 99-, 16-, and 2-fold higher than observed earlier for olive fruit, aloe leaves, and ginseng oil, respectively. The concentration of total carotenoids was found to be higher in oil recovered from the pomace of yellow crab apple Berzukroga dzeltenais, while the lowest in oil extracted from the pomace of Bernu prieks apple, corresponding to 14.5 and $5.1 \mathrm{mg} \mathrm{mL}^{-1}$, respectively. The results of scavenging capacity assay using the DPPH ${ }^{\bullet}$ radicals did not show correlation between the total bound FAs $\left(R^{2}=0.2191\right)$, tocopherols $\left(R^{2}=0.0086\right)$ or carotenoids $\left(R^{2}=0.2306\right)$ in apple pomace oils, which suggests that radical scavenging $\left(\mathrm{DPPH}^{\bullet}\right)$ with each compound is an independent process, the overall success of which depends predominantly on the chemical structure of a particular biologically active compound, rather than on the concentration. The only pomace oil from M. cv. "Ola" showed an inhibition of both Gram-positive and Gram-negative test cultures, while, to a lesser extent, the ability to inhibit only Gram-negative pathogenic bacteria was attributed to pomace oil from $M$. Berzukroga dzeltenais.

Supplementary Materials: The following are available online at http://www.mdpi.com/2223-7747/7/4/90/s1, Table S1: The list of fruit used in this study; Table S2: Calibration data for the standards.

Author Contributions: V.R. and K.J.-R. Conceptualization; V.R., J.K., K.J.-R. and A.V. Formal analysis; V.R., J.K. Methodology; J.K., T.P. and M.K. Writing—review and editing; I.D. Resources; and V.R. Writing-original draft and Writing-review and editing.

Funding: This work was funded by the "Post-doctoral Research Aid" of the Specific Objective 1.1.1 "To increase the research and innovative capacity of scientific institutions of Latvia and the ability to attract external financing, investing in human resources and infrastructure" of the Operational Programme "Growth and Employment", Project No. 1.1.1.2/VIAA/1/16/201, "The development of new synbiotic food products using enzymatic hydrolysis of plant by-product".

Conflicts of Interest: The authors declare no conflict of interest. The funders had no role in the design of the study; in the collection, analyses, or interpretation of data; in the writing of the manuscript, and in the decision to publish the results. 


\section{References}

1. FAOSTAT. In: FAO Stat. Database. 2018. Available online: http://www.fao.org/faostat/en/\#data/QC (accessed on 10 May 2018).

2. Statistica. Statistics Portal. 2016. Available online: https://www.statista.com/statistics/423198/productionvolume-of-apple-juice-eu/ (accessed on 1 May 2018).

3. AICV. European Cider Trends. 2014. Available online: http://aicv.org/file.handler?f=CiderTrends2014.pdf (accessed on 10 May 2018).

4. Stenmarck, Å.; Jensen, C.; Quested, T.; Moates, G. Estimates of European Food Waste Levels. 2016. Available online: http:/ / www.eu-fusions.org/phocadownload/Publications/EstimatesofEuropeanfoodwastelevels. pdf (accessed on 15 January 2017).

5. Kitrytė, V.; Povilaitis, D.; Kraujalienè, V.; Šulniūtè, V.; Pukalskas, A.; Venskutonis, P.R. Fractionation of sea buckthorn pomace and seeds into valuable components by using high pressure and enzyme-assisted extraction methods. LWT Food Sci. Technol. 2017, 1-5. [CrossRef]

6. Radenkovs, V.; Juhnevica-Radenkova, K.; Górnaś, P.; Seglina, D. Non-waste technology through the enzymatic hydrolysis of agro-industrial by-products. Trends Food Sci. Technol. 2018, 77, 64-76. [CrossRef]

7. Gosch, C.; Halbwirth, H.; Kuhn, J.; Miosic, S.; Stich, K. Biosynthesis of phloridzin in apple (Malus domestica Borkh.). Plant Sci. 2009, 176, 223-231. [CrossRef]

8. Xiao, Z.; Zhang, Y.; Chen, X.; Wang, Y.; Chen, W.; Xu, Q.; Li, P.; Ma, F. Extraction, identification, and antioxidant and anticancer tests of seven dihydrochalcones from Malus 'Red Splendor' fruit. Food Chem. 2017, 231, 324-331. [CrossRef] [PubMed]

9. Górnaś, P.; Seglina, D.; Lacis, G.; Pugajeva, I. Dessert and crab apple seeds as a promising and rich source of all four homologues of tocopherol ( $\alpha, \beta, \gamma$ and $\delta)$. LWT Food Sci. Technol. 2014, 59, 211-214. [CrossRef]

10. Stojiljković, D.; Arsić, I.; Tadić, V. Extracts of wild apple fruit (Malus sylvestris (L.) Mill., Rosaceae) as a source of antioxidant substances for use in production of nutraceuticals and cosmeceuticals. Ind. Crop. Prod. 2016, 80, 165-176. [CrossRef]

11. Mihailović, N.R.; Mihailović, V.B.; Kreft, S.; Ćirić, A.R.; Joksović, L.G.; Đurđević, P.T. Analysis of phenolics in the peel and pulp of wild apples (Malus sylvestris (L.) Mill.). J. Food Compos. Anal. 2018, 67, 1-9. [CrossRef]

12. Dadwal, V.; Agrawal, H.; Sonkhla, K.; Joshi, R.; Gupta, M. Characterization of phenolics, amino acids, fatty acids and antioxidant activity in pulp and seeds of high altitude Himalayan crab apple fruits (Malus baccata). J. Food Sci. Technol. 2018. [CrossRef] [PubMed]

13. Anez-Bustillos, L.; Dao, D.T.; Fell, G.L.; Baker, M.A.; Gura, K.M.; Bistrian, B.R.; Puder, M. Redefining essential fatty acids in the era of novel intravenous lipid emulsions. Clin. Nutr. 2017, 37, 784-789. [CrossRef] [PubMed]

14. Górnaś, P.; Rudzińska, M.; Seglina, D. Lipophilic composition of eleven apple seed oils: A promising source of unconventional oil from industry by-products. Ind. Crop. Prod. 2014, 60, 86-91. [CrossRef]

15. Calpe-Berdiel, L.; Escolà-Gil, J.C.; Blanco-Vaca, F. New insights into the molecular actions of plant sterols and stanols in cholesterol metabolism. Atherosclerosis 2009, 203, 18-31. [CrossRef] [PubMed]

16. Derdemezis, C.S.; Filippatos, T.D.; Mikhailidis, D.P.; Elisaf, M.S. Effects of plant sterols and stanols beyond low-density lipoprotein cholesterol lowering. J. Cardiovasc. Pharmacol. Ther. 2010, 15, 120-134. [CrossRef] [PubMed]

17. Llaverias, G.; Escolà-Gil, J.C.; Lerma, E.; Julve, J.; Pons, C.; Cabré, A.; Cofán, M.; Ros, E.; Sánchez-Quesada, J.L.; Blanco-Vaca, F. Phytosterols inhibit the tumor growth and lipoprotein oxidizability induced by a high-fat diet in mice with inherited breast cancer. J. Nutr. Biochem. 2013, 24, 39-48. [CrossRef] [PubMed]

18. Górnaś, P. Unique variability of tocopherol composition in various seed oils recovered from by-products of apple industry: Rapid and simple determination of all four homologues $(\alpha, \beta, \gamma$ and $\delta)$ by RP-HPLC/FLD. Food Chem. 2015, 172, 129-134. [CrossRef] [PubMed]

19. Tuberoso, C.I.G.; Kowalczyk, A.; Sarritzu, E.; Cabras, P. Determination of antioxidant compounds and antioxidant activity in commercial oilseeds for food use. Food Chem. 2007, 103, 1494-1501. [CrossRef]

20. Walia, M.; Rawat, K.; Bhushan, S.; Padwad, Y.S.; Singh, B. Fatty acid composition, physicochemical properties, antioxidant and cytotoxic activity of apple seed oil obtained from apple pomace. J. Sci. Food Agric. 2014, 94, 929-934. [CrossRef] [PubMed] 
21. Pires, T.C.S.P.; Dias, M.I.; Barros, L.; Alves, M.J.; Oliveira, M.B.P.P.; Santos-Buelga, C.; Ferreira, I.C.F.R. Antioxidant and antimicrobial properties of dried Portuguese apple variety (Malus domestica Borkh. cv Bravo de Esmolfe). Food Chem. 2018, 240, 701-706. [CrossRef] [PubMed]

22. Górnaś, P.; Rudzińska, M.; Raczyk, M.; Mišina, I.; Soliven, A.; Lācis, G.; Seglina, D. Impact of species and variety on concentrations of minor lipophilic bioactive compounds in oils recovered from plum kernels. J. Agric. Food Chem. 2016, 64, 898-905. [CrossRef] [PubMed]

23. Jung, J.; Yi, B.; Kim, M.-J.; Lee, J. Influence of different moisture contents on the stability of tocochromanols in bulk oils at $25^{\circ} \mathrm{C}$ storage. J. Am. Oil Chem. Soc. 2018, 197-207. [CrossRef]

24. Kraujalis, P.; Kraujalienè, V.; Kazernavičiūtè, R.; Venskutonis, P.R. Supercritical carbon dioxide and pressurized liquid extraction of valuable ingredients from Viburnum opulus pomace and berries and evaluation of product characteristics. J. Supercrit. Fluids 2017, 122, 99-108. [CrossRef]

25. Rodrigues, J.; Miranda, I.; Furquim, L.; Gominho, J.; Vasconcelos, M.; Barradas, G.; Pereira, H.; Bianchi-de-Aguiar, F.; Ferreira-Dias, S. Storage stability of Jatropha curcas L. oil naturally rich in gamma-tocopherol. Ind. Crop. Prod. 2015, 64, 188-193. [CrossRef]

26. Peschel, S.; Franke, R.; Schreiber, L.; Knoche, M. Composition of the cuticle of developing sweet cherry fruit. Phytochemistry 2007, 68, 1017-1025. [CrossRef] [PubMed]

27. Dong, X.; Rao, J.; Huber, D.J.; Chang, X.; Xin, F. Wax composition of "Red Fuji” apple fruit during development and during storage after 1-methylcyclopropene treatment. Hortic. Environ. Biotechnol. 2012, 53, 288-297. [CrossRef]

28. DellaPenna, D.; Mène-Saffrané, L. Vitamin E. In Advances in Botanical Research; Elsevier Science: Burlington, NJ, USA, 2011; Volume 59, pp. 179-227, ISBN 9780123858511.

29. Traber, M.G.; Atkinson, J. Vitamin E, antioxidant and nothing more. Free Radic. Biol. Med. 2007, 43, 4-15. [CrossRef] [PubMed]

30. Li, G.X.; Lee, M.J.; Liu, A.B.; Yang, Z.; Lin, Y.; Shih, W.J.; Yang, C.S. $\delta$-tocopherol is more active than $\alpha$ or $\gamma$-tocopherol in inhibiting lung tumorigenesis in vivo. Cancer Prev. Res. 2011, 4, 404-413. [CrossRef] [PubMed]

31. da Silva, A.C.; Jorge, N. Bioactive compounds of oils extracted from fruits seeds obtained from agroindustrial waste. Eur. J. Lipid Sci. Technol. 2017, 119, 1-5. [CrossRef]

32. Katan, M.B.; Grundy, S.M.; Jones, P.; Law, M.; Miettinen, T.; Paoletti, R. Efficacy and safety of plant stanols and sterols in the management of blood cholesterol levels. Mayo Clin. Proc. 2003, 78, 965-978. [CrossRef]

33. Saleem, M. Lupeol, a novel anti-inflammatory and anti-cancer dietary triterpene. Cancer Lett. 2009, 285, 109-115. [CrossRef] [PubMed]

34. Santiago, L.A.; Mayor, A.B.R. Lupeol: An antioxidant triterpene in Ficus pseudopalma Blanco (Moraceae). Asian Pac. J. Trop. Biomed. 2014, 4, 109-118. [CrossRef]

35. Siddique, H.R.; Saleem, M. Beneficial health effects of lupeol triterpene: A review of preclinical studies. Life Sci. 2011, 88, 302-306. [CrossRef] [PubMed]

36. Santos, M.F.G.; Alves, R.E.; Roca, M. Carotenoid composition in oils obtained from palm fruits from the Brazilian Amazon. Grasas y Aceites 2015, 66, e086. [CrossRef]

37. Fromm, M.; Bayha, S.; Kammerer, D.R.; Carle, R. Identification and quantitation of carotenoids and tocopherols in seed oils recovered from diffrent Rosaceae Species. J. Agric. Food Chem. 2012, 60, 10733-10742. [CrossRef] [PubMed]

38. Biesalski, H.K.; Böhles, H.; Esterbauer, H.; Fürst, P.; Gey, F.; Hundsdörfer, G.; Kasper, H.; Sies, H.; Weisburger, J. Antioxidant vitamins in prevention. Clin. Nutr. 1997, 16, 151-155. [CrossRef]

39. Prescha, A.; Grajzer, M.; Dedyk, M.; Grajeta, H. The Antioxidant Activity and Oxidative Stability of Cold-Pressed Oils. J. Am. Oil Chem. Soc. 2014, 91, 1291-1301. [CrossRef] [PubMed]

40. Wang, W.; Wu, N.; Zu, Y.G.; Fu, Y.J. Antioxidative activity of Rosmarinus officinalis L. essential oil compared to its main components. Food Chem. 2008, 108, 1019-1022. [CrossRef] [PubMed]

41. Radenkovs, V.; Püssa, T.; Juhnevica-Radenkova, K.; Anton, D.; Seglina, D. Phytochemical characterization and antimicrobial evaluation of young leaf/shoot and press cake extracts from Hippophae rhamnoides L. Food Biosci. 2018, 24, 56-66. [CrossRef]

42. Andrews, J.M. Determination of minimum inhibitory concentrations. J. Antimicrob. Chemother. 2001, 48 (Suppl. 1), 5-16. [CrossRef] 
43. Balouiri, M.; Sadiki, M.; Ibnsouda, S.K. Methods for in vitro evaluating antimicrobial activity: A review. J. Pharm. Anal. 2016, 6, 71-79. [CrossRef] [PubMed]

44. Guil-Guerrero, J.L.; Ramos, L.; Moreno, C.; Zúñiga-Paredes, J.C.; Carlosama-Yepez, M.; Ruales, P. Antimicrobial activity of plant-food by-products: A review focusing on the tropics. Livest. Sci. 2016, 189, 32-49. [CrossRef]

45. Mizunaga, S.; Kamiyama, T.; Fukuda, Y.; Takahata, M.; Mitsuyama, J. Influence of inoculum size of Staphylococcus aureus and Pseudomonas aeruginosa on in vitro activities and in vivo efficacy of fluoroquinolones and carbapenems. J. Antimicrob. Chemother. 2005, 56, 91-96. [CrossRef] [PubMed]

46. Dilika, F.; Bremner, P.D.; Meyer, J.J.M. Antibacterial activity of linoleic and oleic acids isolated from Helichrysum pedunculatum: A plant used during circumcision rites. Fitoterapia 2000, 71, 450-452. [CrossRef]

47. Juhneviča-Radenkova, K.; Radenkovs, V. Influence of 1-Methylcyclopropene and ULO conditions on sensory characteristics of apple fruit grown in Latvia. J. Hortic. Res. 2016, 24, 37-46. [CrossRef]

48. Ruiz, R.P. Gravimetric Measurements of Water. In Handbook of Food Analytical Chemistry, Water, Proteins, Enzymes, Lipids, and Carbohydrates; Wrolstad, R.E., Acree, T.E., Decker, E.A., Penner, M.H., Reid, D.S., Schwartz, S.J., Shoemaker, C.F., Smith, D., Sporns, P., Eds.; John Wiley and Sons Inc.: Hoboken, NJ, USA, 2005; pp. 5-33, ISBN 9780471709084.

49. Abdolshahi, A.; Majd, M.H.; Rad, J.S.; Taheri, M.; Shabani, A.; Teixeira da Silva, J.A. Choice of solvent extraction technique affects fatty acid composition of pistachio (Pistacia vera L.) oil. J. Food Sci. Technol. 2015, 52, 2422-2427. [CrossRef] [PubMed]

50. Lelacheur, R.M.; Sonnenberg, L.B.; Singer, P.C.; Christman, R.F.; Charles, M.J. Identification of carbonyl compounds in environmental samples. Environ. Sci. Technol. 1993, 27, 2745-2753. [CrossRef]

51. Van Den Dool, H.; Kratz, P.D. A generalization of the retention index system including linear temperature programmed gas-liquid partition chromatography. J. Chromatogr. A 1963, 11, 463-471. [CrossRef]

52. Górnaś, P.; Siger, A.; Czubinski, J.; Dwiecki, K.; Seglina, D.; Nogala-Kalucka, M. An alternative RP-HPLC method for the separation and determination of tocopherol and tocotrienol homologues as butter authenticity markers: A comparative study between two European countries. Eur. J. Lipid Sci. Technol. 2014, 116, 895-903. [CrossRef]

53. Biehler, E.; Mayer, F.; Hoffmann, L.; Krause, E.; Bohn, T. Comparison of 3 spectrophotometric methods for carotenoid determination in frequently consumed fruits and vegetables. J. Food Sci. 2010, 75. [CrossRef] [PubMed]

54. Rao, A.V.; Rao, L.G. Carotenoids and human health (Review). Pharmacol. Res. 2007, 55, 207-216. [CrossRef] [PubMed]

55. Li, X.; Wu, X.; Huang, L. Correlation between antioxidant activities and phenolic contents of radix Angelicae sinensis (Danggui). Molecules 2009, 14, 5349-5361. [CrossRef] [PubMed] 